\title{
Estimate of genetic gain in popcorn after cycles of phenotypic recurrent selection
}

\author{
H.J. Ematné ${ }^{1}$, J.A.R. Nunes ${ }^{1}$, K.O.G. Dias ${ }^{1}$, P.E.R. Prado ${ }^{2}$ and J.C. Souza ${ }^{1}$ \\ ${ }^{1}$ Departmento de Biologia, Universidade Federal de Lavras, Lavras, MG, Brasil \\ ${ }^{2}$ Syngenta Seeds, Uberlândia, MG, Brasil \\ Corresponding author: H.J. Ematné \\ E-mail: so_hugo85@yahoo.com.br \\ Genet. Mol. Res. 15 (2): gmr. 15026860 \\ Received May 27, 2015 \\ Accepted January 14, 2016 \\ Published May 20, 2016 \\ DOI http://dx.doi.org/10.4238/gmr.15026860
}

\begin{abstract}
Popcorn is widely consumed in Brazil, yet there are few breeding programs for this crop. Recurrent selection (RS) is a viable breeding alternative for popcorn; however, the gains achieved must be frequently checked. The aim of this study was to assess the effect of selection for grain type (round and pointed) after four cycles of phenotypic RS on the main agronomic traits of popcorn, to estimate the genetic gain achieved for the trait of expansion volume (EV), and to obtain estimates of phenotypic correlations for the main traits of the crop in the UFLA E and UFLA R populations. The zero, one, two, and three cycles of the UFLA E and UFLA R populations, the fourth cycle, and the controls IAC-112 and IAC-125 were used. The experiments were conducted at the experimental farm of Universidade Federal de Lavras (UFLA; Environment 1) and at the experimental area of the Genetics and Plant Breeding Sector of the Department of Biology at UFLA (Environment 2) in the 2010/11 crop season. Nine agronomic traits were evaluated, including EV and grain yield (GY). The UFLA $\mathrm{R}$ and UFLA E populations showed similar behavior for all evaluated traits. The type of grain did not affect the genetic gain for EV, which was 5 and $3.7 \%$ in each cycle carried out in the UFLA E and UFLA $\mathrm{R}$ population, respectively. Phenotypic selection carried out during
\end{abstract}


recombination for $\mathrm{EV}$ is an effective method for increasing expression of the trait. EV and GY did not show a linear association.

Key words: Recurrent selection; Gain from selection; Expansion volume

\section{INTRODUCTION}

Most popcorn consumed in Brazil is derived from cultivars with imported seed (Scapim et al., 2006). There are few breeding programs in Brazil dedicated to this crop even though it has a strong social orientation, providing high economic return, particularly in the informal economy, which is well above that obtained by the common corn crop (Rangel et al., 2011).

Popcorn breeding programs seek to develop populations with high grain quality and grain yield (GY); this is measured by expansion capacity (EV). There are reports that these traits exhibit a negative association, and there may be a greater or lesser degree of association depending on the genetic base of the population (Carpentieri-Pípolo et al., 2002; Daros et al., 2004a).

Because genetic control of EV and GY, among other traits, is certainly polygenic, it is necessary to conduct successive selection cycles (recurrent selection, RS) to achieve success (Hallauer et al., 2010). RS has been successfully carried out in popcorn breeding in both the present population (Ematné et. al., 2012) and under different conditions and using other populations (Daros et al., 2004b; Pacheco et al., 2005; Santos et al., 2008).

During RS programs, it is necessary to periodically assess whether there are gains from selection in order to check how has been improved the populations under study, and also to quantify the genetic gain for target traits obtain (Hallauer et al., 2010). Therefore, the aim of the present study was to assess the effect of selection for grain type after four cycles of phenotypic $\mathrm{RS}$ on the main agronomic traits of popcorn, to estimate the genetic gain achieved for the EC trait, and to obtain estimates of phenotypic correlations for the main traits of the crop.

\section{MATERIAL AND METHODS}

The populations UFLAE, cycles zero, one, two, and three (UFLA-E 0, UFLA-E 1, UFLA-E 2, and UFLA-E 3); UFLAR, cycles zero, one, two, and three (UFLA-R 0, UFLA-R 1, UFLA-R 2, and UFLA-R 3); UFLA C4; and the controls IAC-112 (modified single cross hybrid), and IAC-125 (top cross hybrid) were used.

The populations UFLA-E 1, UFLA-E 2, UFLA-R 1, and UFLA-R 2 were obtained as described by Ematné et al. (2012), and the populations UFLA-E 0 and UFLA-R 0 were derived from the first selection for grain type (rounded or pointed) of the original UFLA population (Ematné et al., 2012).

The 20 best half-sib progenies (HSP) of the UFLA-E 2 population were recombined according to the modified Irish method, in a time-isolated field (Hallauer et al., 2010). Recombination of the HSP was performed according to the experimental model, i.e., a randomized complete block design with three replications. Nevertheless, for every three pollen receptor plots (detassled plots), a pollinating row was introduced, which was composed of an equal mixture of the 20 HSPs. After obtaining the recombinant progenies, a sample was removed, thus constituting the UFLA-E 3 population. The HSPs were assessed for the GY and EV traits. Using selection between and within progenies, the 15 best HSPs were selected. 
An analogous procedure was carried out to obtain the UFLA-R 3 population. The UFLA-C4 population, was obtained through recombination of the 15 HSP selected in the UFLA-E and -R populations of the third cycle, jointly, according to the time-isolated modified Irish method.

Experiments assessing the selection cycles and controls, were conducted at the Universidade Federal de Lavras (UFLA) experimental farm (Environment 1), located in the municipality of Lavras, MG, Brazil, at $951 \mathrm{~m}$ altitude, $21^{\circ} 12^{\prime} \mathrm{S}$ latitude and $44^{\circ} 58^{\prime} \mathrm{W}$ longitude, and at the experimental area of the Genetics and Plant Breeding Sector of the Department of Biology of UFLA (Environment 2), located in Lavras, MG, on the UFLA campus at $918 \mathrm{~m}$ altitude, $21^{\circ} 14^{\prime} \mathrm{S}$ latitude and $40^{\circ} 17^{\prime} \mathrm{W}$ longitude.

Experiments were planted in the 2010/11 crop season under dryland conditions. Crop treatments were those recommended for the corn crop in the no-tillage system for the southern region of Minas Gerais. The experimental design for both environments was a complete randomized block design with seven replications in Environment 1 and four in Environment 2. Plots consisted of two 3-m rows at a spacing of $0.6 \mathrm{~m}$, with four plants per linear meter.

The traits evaluated per plot in the two environments were plant height $(\mathrm{PH})$; ear height (EH); prolific plants index (PI); ear diameter (ED); cob diameter (CD); ear length (EL); stalk lodging (BS); grain yield GY), corrected for the ideal stand of plants per plot (24 plants) and for standard moisture of $13 \%$, and expansion volume $(E V)$ in $\mathrm{mL} / \mathrm{g}$. In each plot, three 30 -g grain samples were assessed in an 800-W microwave oven for 3 min (180 s) according to the modified method described by Matta and Viana (2001). The expanded popcorn was measured in a 1000 - $\mathrm{mL}$ graduated cylinder.

All traits were subjected to individual analyses of variance with additional controls, considering the mean value per plot. Joint analyses was carried out after verification of the homogeneity of residual variance for each trait in the two environments.

The phenotypic mean values obtained from joint analysis were compared by the cluster analysis method for grouping means as proposed by Scott and Knott (1974), considering a 5\% level of probability. Experimental precision was estimated by selective accuracy (Resende and Duarte, 2007). Linear regression was obtained for the estimate of genetic gain with the dependent variable $(\mathrm{X})$ being the number of cycles and the independent variable $(\mathrm{Y})$ being the EV. The phenotypic correlations between the traits evaluated were estimated and their significance verified by the $t$-test at a $5 \%$ level of probability. Analysis was carried out by the statistical software Genes (Cruz and Carneiro, 2004).

\section{RESULTS AND DISCUSSION}

In these experiments, good estimates of selective accuracy were obtained (which quantifies experimental quality), with variation ranging from 40 to $92 \%$ for the PI and EV traits, respectively (Table 1). For the traits whose genotype source of variation was significant $(\mathrm{P}<0.05)$, accuracy was above $78 \%$ (Table 1), which is classified as high precision according to Resende and Duarte (2007).

According to joint analyses (Table 1), the EV, EL, and CD traits were significant $(\mathrm{P}<0.05)$ for the genotype and cycle source of variation, i.e., the cycles differ for these traits (Table 1). This situation was expected for $\mathrm{EV}$ because this trait was prioritized with advancing generations.

The environment source of variation found that variation occurred between environments for the EV, GY, PI, and BS traits; however, it did not verify interaction between he genotypes in the different environments, i.e., the genotypes exhibited consistent behavior (Table 1). 
Table 1. Summary of combined analyses of variance of expansion volume (EV, $\mathrm{mL} / \mathrm{g})$, grain yield (GY, ton/ ha), prolific plants index $(\mathrm{PI})$, ear length $(\mathrm{EL}, \mathrm{cm})$, ear diameter $(\mathrm{ED}, \mathrm{cm})$, cob diameter $(\mathrm{CD}, \mathrm{cm})$, plant height $(\mathrm{PH}, \mathrm{cm})$, ear height $(\mathrm{EH}, \mathrm{cm})$, and broken stalks (BS, transformed to square root plus 1$)$, assessed in the populations of the different cycles and in the controls IAC-112 and IAC-125. Lavras, MG, Brazil, 2011.

\begin{tabular}{|c|c|c|c|c|c|c|c|c|c|c|}
\hline \multirow[t]{2}{*}{ SV } & \multirow[t]{2}{*}{ d.f. } & \multicolumn{9}{|c|}{ Mean square } \\
\hline & & EV & GY & PI & EL & ED & $\mathrm{CD}$ & PH & EH & BS \\
\hline Location (L) & 1 & $188.29 *$ & $1.48^{*}$ & $0.83^{*}$ & $0.00^{\text {ns }}$ & $2.86^{\mathrm{ns}}$ & $1.6^{\mathrm{ns}}$ & $0.00^{\mathrm{ns}}$ & $0.00^{\mathrm{ns}}$ & $74.5^{*}$ \\
\hline Block (B) & 9 & 5.07 & 0.44 & 0.03 & 1.67 & 2.77 & 0.6 & 0.09 & 0.06 & 0.5 \\
\hline Genotype (G) & 10 & $50.84 *$ & $0.20^{\mathrm{ns}}$ & $0.09^{\text {ns }}$ & $2.43^{*}$ & $3.00^{\mathrm{ns}}$ & $3.0^{*}$ & $0.05^{*}$ & $0.01^{\mathrm{ns}}$ & $0.6^{*}$ \\
\hline Cycle (C) & 8 & $31.67^{*}$ & $0.19^{\mathrm{ns}}$ & $0.05^{\mathrm{ns}}$ & $2.47^{*}$ & $2.37^{\mathrm{ns}}$ & $1.8^{*}$ & $0.01^{\mathrm{ns}}$ & $0.01^{\mathrm{ns}}$ & $0.2^{\mathrm{ns}}$ \\
\hline Control (T) & 1 & $0.04^{\mathrm{ns}}$ & $0.41^{\mathrm{ns}}$ & $0.22^{\mathrm{ns}}$ & $2.95^{\mathrm{ns}}$ & $0.53^{\mathrm{ns}}$ & $7.3^{*}$ & $0.17^{*}$ & $0.06^{*}$ & $0.4^{*}$ \\
\hline $\mathrm{CxT}$ & 1 & $254.96^{*}$ & $0.04^{\mathrm{ns}}$ & $0.22^{\text {ns }}$ & $1.52^{\text {ns }}$ & $10.51^{*}$ & $7.9^{*}$ & $0.19^{*}$ & $0.00^{\mathrm{ns}}$ & $3.4^{*}$ \\
\hline $\mathrm{GxL}$ & 10 & $7.88^{\mathrm{ns}}$ & $0.17^{\mathrm{ns}}$ & $0.03^{\text {ns }}$ & $0.84^{\text {ns }}$ & $1.09^{\text {ns }}$ & $0.7^{\mathrm{ns}}$ & $0.03^{\text {ns }}$ & $0.01^{\mathrm{ns}}$ & $0.2^{\mathrm{ns}}$ \\
\hline $\mathrm{C} \times \mathrm{L}$ & 8 & $9.01^{\mathrm{ns}}$ & $0.21^{\mathrm{ns}}$ & $0.03^{\text {ns }}$ & $0.70^{\text {ns }}$ & $1.02^{\mathrm{ns}}$ & $0.6^{\mathrm{ns}}$ & $0.03^{\text {ns }}$ & $0.01^{\mathrm{ns}}$ & $0.1^{\mathrm{ns}}$ \\
\hline $\mathrm{T} \times \mathrm{L}$ & 1 & $6.70^{\mathrm{ns}}$ & $0.01^{\mathrm{ns}}$ & $0.00^{\text {ns }}$ & $2.76^{\mathrm{ns}}$ & $2.66^{\mathrm{ns}}$ & $0.7^{\mathrm{ns}}$ & $0.00^{\mathrm{ns}}$ & $0.00^{\mathrm{ns}}$ & $0.4^{\mathrm{ns}}$ \\
\hline C x L vs T x L & 1 & $50.08 *$ & $0.00^{\mathrm{ns}}$ & $0.04 *$ & $0.29^{\mathrm{ns}}$ & $2.06^{*}$ & $1.5^{*}$ & $0.03 *$ & $0.00^{\mathrm{ns}}$ & $0.6^{*}$ \\
\hline Error & 90 & 7.75 & 0.37 & 0.07 & 0.88 & 1.88 & 0.7 & 0.01 & 0.01 & 0.2 \\
\hline Accuracy & & $92 \%$ & - & $40 \%$ & $80 \%$ & $61 \%$ & $87 \%$ & $78 \%$ & $56 \%$ & $78 \%$ \\
\hline \multicolumn{5}{|l|}{ Contrast } & \multicolumn{3}{|c|}{ Location } & \multicolumn{3}{|c|}{ Mean Square } \\
\hline \multicolumn{5}{|c|}{$\mathrm{Y}(1)$ : Cycle $0,1,2$,and $3 \mathrm{E}$ vs Cycle 4} & \multicolumn{3}{|c|}{ Combined } & \multicolumn{3}{|c|}{$77.157^{*}$} \\
\hline \multicolumn{5}{|c|}{$\mathrm{Y}(2)$ : Cycle $0,1,2$, and $3 \mathrm{R} v s$ Cycle 4} & \multicolumn{3}{|c|}{ Combined } & \multicolumn{3}{|c|}{$72.281^{*}$} \\
\hline \multicolumn{5}{|c|}{ Y(3): Cycle4 vs Cycles (0E; 0R; 1E; 1R; 2E; 2R; 3E; 3R) } & \multicolumn{3}{|c|}{ Combined } & \multicolumn{3}{|c|}{$82.998^{*}$} \\
\hline
\end{tabular}

${ }_{\mathrm{ns}}, *$ not significant and significant at $5 \%$, respectively, by the $\mathrm{F}$ test.

The traits $\mathrm{BS}, \mathrm{PH}$, and $\mathrm{EH}$, did not exhibit variability for the cycle source of variation (Table 1), and exhibited mean values of 201-210 and 106-117 cm for PH and EH, respectively (Table 2). Freitas Júnior et al. (2009) assessed 200 families of full siblings from the fourth cycle of recurrent selection in the UNB-2U population of popcorn in two environments. Thirty families were selected with maximum variation ranging from 216 to $179 \mathrm{~cm}$ and from 135 to $106 \mathrm{~cm}$ for the PH and EH traits, respectively. Rangel et al. (2011), giving continuity to the studies of Freitas Júnior et al. (2009), obtained estimates for PH and EH, for the fifth selection cycle, of 194.55 and $120.74 \mathrm{~cm}$ in the overall mean, respectively. For the controls, estimates of 193.96 and $116.17 \mathrm{~cm}$ for PH and EH, respectively, were obtained using the same controls as the present study. Therefore, it may be inferred that the assessed populations exhibited PH and EH standards that are acceptable to the market, since they did not differ from the controls (Table 2), which are commercial hybrids.

Among the EL, ED, and CD traits, only CD resulted in the formation of two groups by mean cluster analysis (Table 2). The selection made in cycle three contributed to the reduction in $\mathrm{CD}$, while it did not reduce ED. This shows that the fourth cycle exhibits larger grains, which are favorable for increasing the GY traits in subsequent cycles. For the PI trait, variation was not identified (maximum amplitude among the cycles was 1.21-1.44). These estimates are consistent with those obtained by Viana (2007) by comparing three selection cycles of the Beija-Flor population with the original population.

The GY trait did not differ among the cycles and controls $(\mathrm{P}<0.05)$ (Table 1). This observation was confirmed by the cluster analysis method for grouping means (Table 2). Therefore, in comparison with the controls, which are commercial hybrids prominent in the Brazilian market, the populations used in this study have high productive potential.

Matta and Viana (2003), Scapim et al. (2010), and Vieira et al. (2009) used the hybrid IAC-112 and/or IAC-125 as the controls (consistent with those used in the present study) and observed superiority of these hybrids in their studies; however, these hybrids were not superior to the different selection cycles of the present study, which confirms the productive potential of the populations. 
Table 2. Summary of the combined mean values of expansion volume (EV, $\mathrm{ml} / \mathrm{g})$, grain yield (GY, ton/ha), prolific plants index $(\mathrm{PI})$, ear length $(\mathrm{EL}, \mathrm{cm})$, ear diameter $(\mathrm{ED}, \mathrm{cm})$, cob diameter $(\mathrm{CD}, \mathrm{cm})$, plant height $(\mathrm{PH}, \mathrm{cm})$, ear height $(\mathrm{EH}, \mathrm{cm})$, and broken stalks (BS, transformed by square root plus 1$)$, assessed in the populations of the different cycles and in the controls IAC-112 and IAC-125. Lavras, MG, Brazil, 2011.

\begin{tabular}{l|c|c|c|c|c|c|c|c|c}
\hline Genotypes & EC & GY & PI & EL & ED & CD & PH & EH & BS \\
\hline C0.E & $26.22^{\mathrm{b}}$ & $2.81^{\mathrm{a}}$ & $1.44^{\mathrm{a}}$ & $16.03^{\mathrm{a}}$ & $31.71^{\mathrm{a}}$ & $18.30^{\mathrm{a}}$ & $2.10^{\mathrm{a}}$ & $1.12^{\mathrm{a}}$ & $2.15^{\mathrm{a}}$ \\
\hline C0.R & $25.61^{\mathrm{b}}$ & $2.54^{\mathrm{a}}$ & $1.22^{\mathrm{a}}$ & $16.70^{\mathrm{a}}$ & $32.63^{\mathrm{a}}$ & $18.81^{\mathrm{a}}$ & $2.02^{\mathrm{a}}$ & $1.12^{\mathrm{a}}$ & $2.14^{\mathrm{a}}$ \\
\hline C1.E & $25.28^{\mathrm{b}}$ & $2.57^{\mathrm{a}}$ & $1.21^{\mathrm{a}}$ & $15.61^{\mathrm{a}}$ & $31.51^{\mathrm{a}}$ & $18.25^{\mathrm{a}}$ & $2.05^{\mathrm{a}}$ & $1.11^{\mathrm{a}}$ & $1.80^{\mathrm{a}}$ \\
\hline C1.R & $27.48^{\mathrm{b}}$ & $2.80^{\mathrm{a}}$ & $1.24^{\mathrm{a}}$ & $16.26^{\mathrm{a}}$ & $32.24^{\mathrm{a}}$ & $18.50^{\mathrm{a}}$ & $2.01^{\mathrm{a}}$ & $1.06^{\mathrm{a}}$ & $1.95^{\mathrm{a}}$ \\
\hline C2.E & $27.98^{\mathrm{b}}$ & $2.70^{\mathrm{a}}$ & $1.37^{\mathrm{a}}$ & $15.25^{\mathrm{a}}$ & $31.37^{\mathrm{a}}$ & $18.58^{\mathrm{a}}$ & $2.04^{\mathrm{a}}$ & $1.13^{\mathrm{a}}$ & $2.04^{\mathrm{a}}$ \\
\hline $\mathrm{C} 2 . \mathrm{R}$ & $28.86^{\mathrm{a}}$ & $2.63^{\mathrm{a}}$ & $1.33^{\mathrm{a}}$ & $16.38^{\mathrm{a}}$ & $31.61^{\mathrm{a}}$ & $18.82^{\mathrm{a}}$ & $2.02^{\mathrm{a}}$ & $1.08^{\mathrm{a}}$ & $2.23^{\mathrm{a}}$ \\
\hline C3.E & $29.67^{\mathrm{a}}$ & $2.58^{\mathrm{a}}$ & $1.33^{\mathrm{a}}$ & $15.43^{\mathrm{a}}$ & $31.53^{\mathrm{a}}$ & $18.26^{\mathrm{a}}$ & $2.08^{\mathrm{a}}$ & $1.13^{\mathrm{a}}$ & $1.79^{\mathrm{a}}$ \\
\hline C3.R & $27.61^{\mathrm{b}}$ & $2.78^{\mathrm{a}}$ & $1.27^{\mathrm{a}}$ & $16.32^{\mathrm{a}}$ & $32.14^{\mathrm{a}}$ & $19.15^{\mathrm{a}}$ & $2.12^{\mathrm{a}}$ & $1.17^{\mathrm{a}}$ & $2.15^{\mathrm{a}}$ \\
\hline C4 & $30.37^{\mathrm{a}}$ & $2.40^{\mathrm{a}}$ & $1.28^{\mathrm{a}}$ & $15.65^{\mathrm{a}}$ & $31.10^{\mathrm{a}}$ & $17.66^{\mathrm{b}}$ & $2.09^{\mathrm{a}}$ & $1.15^{\mathrm{a}}$ & $1.87^{\mathrm{a}}$ \\
\hline IAC 112 & $31.54^{\mathrm{a}}$ & $2.84^{\mathrm{a}}$ & $1.52^{\mathrm{a}}$ & $15.28^{\mathrm{a}}$ & $30.81^{\mathrm{a}}$ & $17.19^{\mathrm{b}}$ & $2.26^{\mathrm{a}}$ & $1.18^{\mathrm{a}}$ & $1.41^{\mathrm{a}}$ \\
\hline IAC 125 & $31.63^{\mathrm{a}}$ & $2.55^{\mathrm{a}}$ & $1.31^{\mathrm{a}}$ & $16.04^{\mathrm{a}}$ & $31.13^{\mathrm{a}}$ & $18.39^{\mathrm{a}}$ & $2.07^{\mathrm{a}}$ & $1.06^{\mathrm{a}}$ & $1.71^{\mathrm{a}}$ \\
\hline$\overline{\mathrm{X}}_{\text {UFLA-HJE }}$ & 27.90 & 2.61 & 1.32 & 15.59 & 31.44 & 18.21 & 2.07 & 1.12 & 1.93 \\
\hline $\bar{X}_{\text {UFLA-HJR }}$ & 27.98 & 2.63 & 1.26 & 16.26 & 31.94 & 18.58 & 2.05 & 1.11 & 2.06 \\
\hline $\bar{X}_{\text {Controls }}$ & 31.58 & 2.69 & 1.41 & 15.66 & 30.97 & 17.79 & 2.16 & 1.12 & 1.56 \\
\hline
\end{tabular}

Mean values followed by the same letter do not differ among themselves by the Scott-Knott test at a 5\% level of probability.

The UFLA popcorn program has prioritized an increase in the EV trait in populations as selection cycles advance, making use of tandem phenotypic selection in the recombination lots up to cycle three. This is supported by estimates found in the literature that the EV trait shows moderate-to-high heritability, with values ranging from 68.42 to $90.19 \%$ in the mean of the family (Santos et al., 2008; Freitas Júnior et al., 2009; Viana et al., 2010).

Tables 1 and 2 show that the EV trait exhibited significant differences among the selection cycles, being formed of two large groups, with the C4 and C3.E cycles standing out in relation to the others, and with the same popcorn quality as the controls. Overall, it may be observed that the present results are consistent with those reported by Hallauer et al. (2010), who noted that for some traits in corn, performance of three recurrent selection cycles is not sufficient to obtain expressive gains. In the present study, differences among the selection cycles for EV were significantly expressed from the second cycle, which corroborates the findings of Hallauer et al. (2010) and Ematné et al. (2012), who detected small but significant differences from the second selection cycle.

The high EV of the different cycles is noteworthy, and an overall mean value of 27.904 and $27.986 \mathrm{~g} / \mathrm{mL}$ was achieved for the UFLA-E and UFLA-R populations, respectively, and $30.37 \mathrm{~g} / \mathrm{mL}$ was achieved for $\mathrm{C} 4$ (Table 2). These estimates of EV are greater than those reported by Amaral Júnior et al. (2010), Rangel et al. (2011), and Santos et al. (2008) when the fourth and fifth recurrent selection cycles were assessed in the UNB-2U population. This confirms the superiority of populations under study for EV.

The gain estimated for EV in the mean of the two environments for the UFLA-E population was $5 \%(1.268 \mathrm{~mL} / \mathrm{g})$ in each selection cycle with $\mathrm{R}^{2}>0.85$ and for the UFLA-R population, $3.7 \%(0.9644 \mathrm{~mL} / \mathrm{g})$ in each selection cycle (Figure 1). These observations were confirmed by the contrasts $\mathrm{Y}(1), \mathrm{Y}(2)$, and $\mathrm{Y}(3)$ (Table 2), suggesting that phenotypic recurrent selection for EV is an effective strategy. This is because after only four selection cycles, it was possible to observe expressive gains of 20 and $14.5 \%$ for the UFLA-E and UFLA-R populations, respectively, corroborating the conclusions made by Matta and Viana (2003). 


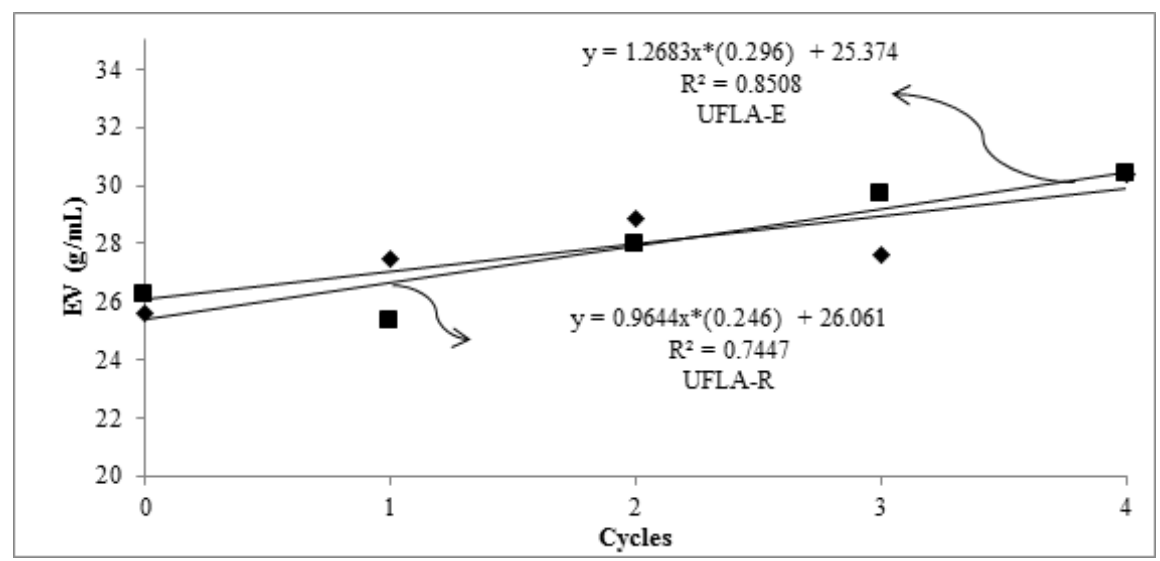

Figure 1. Regression analysis of the mean data of expansion volume $(\mathrm{EV}, \mathrm{mL} / \mathrm{g})$ in the UFLA-E populations, cycles $0,1,2,3$, UFLA-R cycles $0,1,2,3$, UFLA-C4. * Significant at $5 \%$, by $t$ - test. Values between parentheses represent the error associated with the estimate. Lavras, MG, Brazil, 2011.

The data reported here show that the behavior of the two populations (UFLA-E and UFLA-R) was similar. Consequently, maintaining these populations separately would not be justified, since joining them would reduce expenses and expand variability and thus increase the chances of success in subsequent cycles, particularly because the pearl or rounded type of grain has higher market value.

Phenotypic correlations are a measure of association between traits. There was a lack of significant correlation ( $\mathrm{P}<0.05$ ) between GY and EV (Table 3), confirming that the selection undertaken for EV did not affect the GY trait, corroborating the results of Carpentieri Pípolo et al. (2002), and Daros et al. (2004a). This suggests that it is possible to achieve gains for the two traits simultaneously in the populations under study since there is no strong linear association between EV and GY.

Table 3. Estimates of the coefficients of phenotypic correlation between expansion volume (EV, $\mathrm{mL} / \mathrm{g})$, grain yield (GY, ton/ha), prolific plants index (PI), ear length (EL, cm), ear diameter (ED, cm), cob diameter (CD, $\mathrm{cm})$, plant height $(\mathrm{PH}, \mathrm{cm})$, ear height $(\mathrm{EH}, \mathrm{cm})$, and broken stalks (BS, transformed by square root plus 1 , assessed in the populations of the different cycles and in the controls IAC-112 and IAC-125. Lavras, MG, Brazil, 2011.

\begin{tabular}{l|c|c|c|c|c|c|c|c}
\hline & ED & CD & GY & PI & PH & EH & EC & BS \\
\hline EL & $0.81^{*}$ & 0.6 & 0.25 & -0.3 & -0.27 & -0.22 & -0.35 & $0.67^{*}$ \\
\hline ED & & $0.67^{*}$ & 0.41 & -0.4 & -0.32 & -0.16 & -0.55 & 0.43 \\
\hline CD & & & 0.57 & -0.07 & -0.18 & -0.04 & -0.35 & $0.69^{*}$ \\
\hline GY & & & & 0.36 & 0.05 & -0.25 & -0.37 & 0.46 \\
\hline FI & & & & & 0.39 & 0.09 & 0.24 & 0.33 \\
\hline PH & & & & & & $0.79^{*}$ & -0.22 & -0.08 \\
\hline EH & & & & & & & 0.18 & -0.05 \\
\hline EC & & & & & & & & -0.22 \\
\hline
\end{tabular}

*Significant by the $t$-test at the level of $5 \%$ probability.

The phenotypic correlations between the traits $\mathrm{ED}$ and $\mathrm{CD}, \mathrm{EH}$ and $\mathrm{PH}, \mathrm{EL}$ and $\mathrm{BS}$, and $\mathrm{BS}$ and $\mathrm{CD}$ show positive and significant $(\mathrm{P}<0.05)$ associations by the $t$-test (Table 3 ).

In summary, greater attention should be given to the GY trait in future cycles together 
with EV; that is, other breeding strategies should be adopted in the Popcorn Breeding Program of UFLA which take the GY and EV traits into consideration simultaneously. This is because phenotypic selection for EV in the unit of recombination is effective at increasing EV and not very effective at increasing GY, although it did not contribute to a reduction in this trait.

In conclusion, the populations assessed (UFLA-R and UFLA-E) all exhibited similar behavior as the selection cycles advanced for all evaluated traits. The grain type (rounded or pointed) did not influence the genetic gain. Gain achieved from recurrent selection for expansion volume in the UFLA-E population was $5 \%$ per cycle, and $3.7 \%$ for the UFLA-R population. There was no association between expansion volume and yield traits association.

\section{ACKNOWLEDGMENTS}

The authors thank the research sponsoring agencies - Fundação de Amparo à Pesquisa do Estado de Minas Gerais (FAPEMIG), Conselho Nacional de Desenvolvimento Científico e Tecnológico (CNPq), and Coordenadoria de Aperfeiçoamento de Ensino Superior (CAPES) - for financial assistance.

\section{REFERENCES}

Amaral Júnior AT, Freitas Júnior SP, Rangel RM, Pena GF, et al. (2010). Improvement of a popcorn population using selection indexes from a fourth cycle of recurrent selection program carried out in two different environments. Genet. Mol. Res. 9: 340-347. http://dx.doi.org/10.4238/vol9-1gmr702

Carpentieri-Pípolo V, Takahaschi HW, Endo RM and Seifert AL (2002). Correlações entre caracteres quantitativos em milho pipoca. Hortic. Bras. 20: 551-554. http://dx.doi.org/10.1590/S0102-05362002000400008

Cruz CD and Carneiro PCS (2004). Modelos biométricos aplicados ao melhoramento genético. (volume 1 - 3a. eds.), Editora UFV, Viçosa, MG. 480p.

Daros M, Amaral Júnior AT, Pereira MG, Santos FS, et al. (2004a). Correlações entre caracteres agronômicos em dois ciclos de seleção recorrente em milho-pipoca. Cienc. Rural 34: 1389-1394. http://dx.doi.org/10.1590/S0103$\underline{84782004000500010}$

Daros M, Amaral Júnior AT and Pereira MG (2004b). Genetic gain for grain yield and popping expansion in full-sib recurrent selection in popcorn. Crop Breed. Appl. Biotechnol. 2: 339-344. http://dx.doi.org/10.12702/1984-7033. $\underline{\mathrm{v} 02 \mathrm{n} 03 \mathrm{a} 03}$

Ematné HJ, Souza JC, Biudes GB, Nunes JAR, et al. (2012). Genetic progress of phenotypic recurrent selection in popcorn. Cienc. Agrotec. 36: 25-30.

Freitas Júnior SP, Amaral Júnior AT, Rangel RM and Viana AP (2009). Genetic gains in popcorn by full-sib recurrent selection. Crop Breed. Appl. Biotechnol. 9: 1-7. http://dx.doi.org/10.12702/1984-7033.v09n01a01

Hallauer AR, Carena MJ and Miranda Filho JB (2010). Quantitative Genetics in Maize Breeding. Springer, New York.

Matta FP and Viana JMS (2003). Eficiências relativas de seleção entre e dentro de famílias de meios-irmãos em população de milho-pipoca. Cienc. Agrotec. 27: 548-556. http://dx.doi.org/10.1590/S1413-70542003000300008

Matta FP and Viana JMS (2001). Testes de capacidade de expansão em programas de melhoramento de milho pipoca. Sci. Agric. 58: 845-851. http://dx.doi.org/10.1590/S0103-90162001000400029

Pacheco CAP, Gama EEG, Parentoni SN, Santos MX, et al. (2005). Avanços no processo seletivo da variedade de milho pipoca BRS Angela. Revista Brasileira de Milho e Sorgo 4: 436-444. http://dx.doi.org/10.18512/1980-6477/rbms. v4n3p436-444

Rangel RM, Amaral Júnior AT, Gonçalves LS, Freitas Júnior SP, et al. (2011). Análise biométrica de ganhos por seleção em população de milho pipoca de quinto ciclo de seleção recorrente. Rev. Ciênc. Agron 42: 473-481.

Resende MDV and Duarte JB (2007). Precisão e controle de qualidade em experimentos de avaliação de cultivares. Pesqui. Agropec. Trop. 37: 182-194.

Santos JF, Amaral Júnior AT, Freitas Júnior SP, Rangel RM, et al. (2008). Genetic gain prediction of the third recurrent selection cycle in a popcorn population. Acta Sci. Agron. 30: 651-658.

Scapim CA, Braccini AL, Pinto RJB, Amaral Júnior AT, et al. (2006). Componentes genéticos de médias e depressão por endogamia em populações de milho-pipoca. Cienc. Rural 36: 36-41. http://dx.doi.org/10.1590/S0103$\underline{84782006000100006}$ 
Scapim CA, Amaral Júnior AT, Vieira RA, Moterle LM, et al. (2010). Novos compostos de milho-pipoca para o Brasil. Ciênc. Agrár 31: 321-330.

Scott AJ and Knott MA (1974). A cluster analysis method for grouping means in the analysis of variance. Biometrics 30 : 507-512. http://dx.doi.org/10.2307/2529204

Viana JMS (2007). Melhoramento intrapopulacional recorrente de milho-pipoca, com famílias de meios-irmãos. Revista Brasileira de Milho e Sorgo 6: 199-210. http://dx.doi.org/10.18512/1980-6477/rbms.v6n2p199-210

Viana JMS, Sobreira FM, Resende MDV and Faria VR (2010). Multi-trait BLUP in half-sib selection of annual crops. Plant Breed. 129: 599-604. http://dx.doi.org/10.1111/j.1439-0523.2009.01745.x

Vieira RA, Rodovalho MA, Scapim CA, Tessman DJ, et al. (2009). Agronomic performance of new popcorn hybrids in Northwestern Paraná State, Brazil. Acta Sci. Agron. 31: 29-36. 